\title{
First Cytogenetic Profile of Omani Patients with de novo Myelodysplastic Syndromes \\ Comparison with data from Asia, Africa, Europe and North and South America
}

"Achandira M. Udayakumar, ${ }^{1,2}$ Nagla Fawaz, ${ }^{3}$ Anil Pathare, ${ }^{4}$ Shakila Asraf, ${ }^{4}$ Mohammed Al-Huneini, ${ }^{4}$ Khalil Al-Farsi, ${ }^{4}$ Salam Al-Kindi, ${ }^{3}$ Murtadha Al-Khabouri ${ }^{4}$

$$
\begin{aligned}
& \text { أول ملف للجينات الحلوية للمرضى العمانيين المصابين } \\
& \text { بمتلازمة خلل النسج النقوي } \\
& \text { مقارنة مع بيانات من اسيا وافريقيا وامريكا الشمالية والجنوبية النعوي }
\end{aligned}
$$

أشانديرا موثابا أوداياكومار، نجلاء فواز، أنيل باثاري، شاكيلة أسرف، محد الحنيني، خليل الفارسي، سلام الكندي، مرتضى الخابوري

ABSTRACT: Clonal cytogenetic abnormalities have been reported among 30-80\% of patients with myelodysplastic syndromes (MDS); however, 20-70\% of patients with MDS show a normal karyotype that may nevertheless harbour a cryptic genetic alteration. Earlier reports have suggested that the distribution of specific chromosomal aberrations varies among Western and Asian countries, with geographical and ethnic differences in the frequency of specific chromosomal aberrations. This article compared the cytogenetic data of 36 adult Omani patients with MDS to previously reported data from other populations. Differences were noted between the percentages of clonal aberrations and the median age of Omani subjects at presentation in comparison to individuals of different ethnicities and from various geographical locations. To the best of the authors' knowledge, this is the first report to describe the cytogenetic data of patients with MDS from Oman.

Keywords: Cytogenetic Abnormalities; Chromosomal Aberrations; Myelodysplastic Syndromes; Population Heterogeneity; Ethnic Groups; Oman.

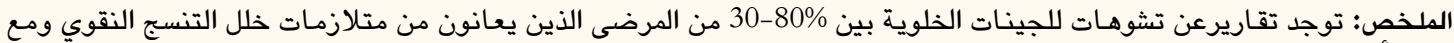

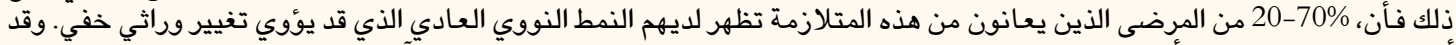

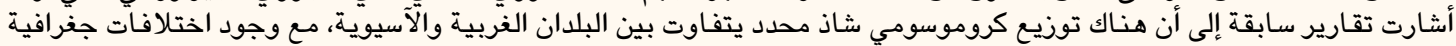

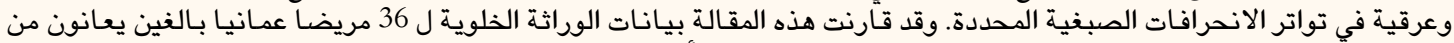

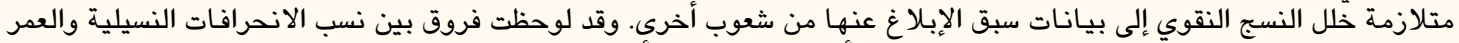

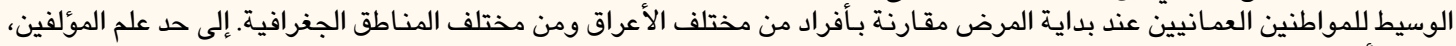

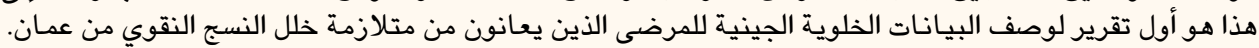

الكلمات المفتاحية: تشوهـات خلوية المنشأ؛ شذوذ الكروموسومات؛ متلازمات خلل التنسج النقوي؛ عدم التجانس السكاني؛ جماعات عرقية؛ عمان.

$\mathrm{M}$

Yelodysplastic Syndromes (MDS) ARE a group of clonal haematopoietic stem cell diseases characterised by cytopaenia, dysplasia in one or more of the major myeloid cell lines, ineffective haematopoiesis and an increased risk of developing acute myeloid leukaemia (AML). ${ }^{1}$ Cytogenetic and molecular abnormalities are key elements in the diagnosis of MDS. Clonal chromosomal abnormalities in MDS have been observed in $30-80 \%$ of patients, depending on the subtype and whether it is de novo or mutageninduced. ${ }^{2,3}$ For the other $20-70 \%$ of MDS patients with normal karyotypes, there is substantial evidence for the presence of submicroscopic alterations-such as point mutations, microdeletions, microamplifications, epigenetic changes or copy number neutral loss of information - which may form the genetic basis of the disease. ${ }^{4-6}$ The percentage of clonal abnormalities in the literature varies between $23-78 \% .^{-9}$

Over time, MDS has been increasingly recognised as a cause of bone marrow failure; however, the precise incidence of de novo MDS is unknown. ${ }^{10}$ Jacobs et al. have suggested that the distribution of specific chromosomal aberrations in MDS varies between Western and Asian countries. ${ }^{11}$ Another report also indicated geographical and ethnic differences in the frequency of specific chromosomal aberrations. ${ }^{12}$ The incidence of chromosomal abnormalities 
Table 1: Characteristics of Omani patients with myelodysplastic syndromes presenting to the Sultan Qaboos University Hospital, Muscat, Oman $(\mathrm{N}=36)$

Characteristic $\quad$ (\%)

Gender

Male

Female

Age in years

Mean/median (range)

$63 / 65(16-86)$

$>60$

$<60$

$13(36.1)$

Peripheral blood count

Median haemoglobin in $\mathrm{g} / \mathrm{dL}$ (range)

$8.7(6.2-14.9)$

Median ANC in x10 1 L (range)

$1.3(0.1-31.5)$

Median platelet count in $\times 10^{9} / \mathrm{L}$ (range)

$77(5-591)$

Cytopaenia

None

Single lineage

Bilineage

Trilineage

Bone marrow blast in \%

$<5$

$27(75.0)$

5-10

$>10$

Therapy

Supportive only

Chemotherapy

Bone marrow transplantation

Hydroxyuraea

Azacitidine

Chelation

MDS subtype*

RA

RARS

RCMD

RAEB

MDS-U

\section{AML transformation}

Yes

No

$\begin{array}{lc}\text { Mortality } & \\ \text { Yes } & 9(25.0) \\ \text { No } & 27(75.0)\end{array}$

ANC = absolute neutrophil count; $M D S=$ myelodysplastic syndromes; $R A=$ refractory anaemia $; R A R S=$ refractory anaemia with ringed sideroblasts; $R C M D=$ refractory cytopaenia with multilineage dysplasia; $R A E B=$ refractory anaemia with excess blasts; $U=$ unclassified; $A M L=$ acute myeloid leukaemia.

"Defined as per the criteria of the World Health Organization..$^{23}$

${ }^{\dagger}$ Including one case of MDS associated with an isolated del $(5 q)$ abnormality.

in Indian population has been reported to vary from $37.5-88 \% .^{13}$ In addition, the frequency of chromosomal abnormalities varies between $37-50 \%$ in China, Thailand, Hong Kong and Japan. ${ }^{13,14}$ Complex aberrations have been more frequently observed in Indian patients as compared to those from other Asian countries. ${ }^{13}$

As such, ethnic and/or geographical differences could be heterogeneous and contribute to clinical, cytogenetic or molecular events leading to MDS. Available reports on the incidence of MDS mostly originate from European countries, although major studies have been conducted in Japan. ${ }^{15-22}$ To the best of the authors' knowledge, this is the first report detailing the cytogenetic profile of Omani patients with MDS. In order to analyse ethno-geographical differences in the pathogenesis of MDS, the current article aimed to compare the cytogenetic findings of Omani patients with de novo MDS with available data from Europe, North and South America, Africa and other Asian countries.

\section{Methods}

Data were collected from all patients with MDS presenting between 2006-2013 to the Department of Haematology at the Sultan Qaboos University Hospital (SQUH), a tertiary care centre in Muscat, Oman. A diagnosis of MDS was made as per the criteria of the World Health Organization (WHO). ${ }^{23}$ Patients who did not fulfill the WHO criteria were excluded. All eligible subjects subsequently had their peripheral blood count recorded. In addition, bone marrow samples were obtained prior to the initiation of any therapy.

Cytogenetic analysis of the bone marrow samples was performed using GTG banding, with karyotypes reported according to the International System for Human Cytogenomic Nomenclature. ${ }^{24}$ At least 20 metaphases were karyotyped and analysed from 24- and 48-hour bone marrow cultures. Clonal 
Table 2: Age/gender distribution across subtypes of Omani patients with myelodysplastic syndromes presenting to the Sultan Qaboos University Hospital, Muscat, Oman ( $\mathrm{N}=36)$

\begin{tabular}{|c|c|c|c|c|c|c|c|}
\hline \multirow[t]{3}{*}{ MDS subtype } & \multicolumn{7}{|c|}{ n (\%) } \\
\hline & \multirow[t]{2}{*}{ Total } & \multicolumn{4}{|c|}{ Age in years } & \multicolumn{2}{|c|}{ Gender } \\
\hline & & $0-20$ & $21-40$ & $41-60$ & $>60$ & Male & Female \\
\hline RA & $8(22.2)$ & $0(0.0)$ & $0(0.0)$ & $2(5.4)$ & $6(16.7)$ & $3(8.3)$ & $5(13.9)$ \\
\hline RARS & $3(8.3)$ & $0(0.0)$ & $0(0.0)$ & $1(2.8)$ & $2(5.6)$ & $3(8.3)$ & $0(0.0)$ \\
\hline RCMD & $11(30.6)$ & $0(0.0)$ & $1(2.7)$ & $4(11.1)$ & $6(16.7)$ & $5(13.9)$ & $6(16.7)$ \\
\hline RAEB & $6(16.7)$ & $1(2.8)$ & $0(0.0)$ & $2(5.6)$ & $3(8.3)$ & $3(8.3)$ & $3(8.3)$ \\
\hline MDS-U & $8(22.2)$ & $0(0.0)$ & $1(2.7)$ & $1(2.8)$ & $6(16.7)$ & $4(11.1)$ & $4(11.1)$ \\
\hline Total & $36(100.0)$ & $1(2.8)$ & $2(5.6)$ & $10(27.8)$ & $23(63.9)$ & $18(50.0)$ & $18(50.0)$ \\
\hline
\end{tabular}

$M D S=$ myelodysplastic syndromes; $R A=$ refractory anaemia $; R A R S=$ refractory anaemia with ringed sideroblasts; $R C M D=$ refractory cytopaenia with multilineage dysplasia; $R A E B=$ refractory anaemia with excess blasts; $U$ = unclassified.

*Defined as per the criteria of the World Health Organization. ${ }^{23}$

Table 3: Cytogenetic prognosis of Omani patients with myelodysplastic syndromes presenting to the Sultan Qaboos University Hospital, Muscat, Oman $(\mathrm{N}=36)$

\begin{tabular}{|c|c|c|c|c|c|c|c|}
\hline \multirow[t]{3}{*}{ Cytogenetic prognosis* } & \multirow{3}{*}{$\begin{array}{l}\text { Cytogenetic } \\
\text { abnormality }\end{array}$} & \multicolumn{6}{|c|}{ n (\%) } \\
\hline & & \multirow[t]{2}{*}{ Total $^{+}$} & \multicolumn{5}{|c|}{ MDS subtype } \\
\hline & & & RA & RARS & RCMD & RAEB & MDS-U $\mathbf{U}^{\neq}$ \\
\hline Very good & $-Y$ & $1(2.8)$ & - & - & - & - & $1(2.8)$ \\
\hline \multirow[t]{4}{*}{ Good } & Normal & $23(63.9)$ & $6(16.7)$ & $2(5.6)$ & $8(22.2)$ & $4(11.1)$ & $3(8.3)$ \\
\hline & $\operatorname{del}(5 q)$ & $1(2.8)$ & $1(2.7)$ & - & - & - & - \\
\hline & $\operatorname{del}(12 p)$ & $0(0.0)$ & - & - & - & - & - \\
\hline & $\operatorname{del}(20 q)$ & $0(0.0)$ & - & - & - & - & - \\
\hline \multirow{5}{*}{$\begin{array}{l}\text { Intermediate (all single/double } \\
\text { abnormalities) }\end{array}$} & $\operatorname{del}(7 q)$ & $0(0.0)$ & - & - & - & - & - \\
\hline & +8 & $2(5.6)$ & $1(2.8)$ & - & - & $1(2.8)$ & $1(2.8)$ \\
\hline & $\mathrm{i}(17)(\mathrm{q} 10)$ & $1(2.8)$ & - & - & - & - & $1(2.8)$ \\
\hline & +19 & $0(0.0)$ & - & - & - & - & - \\
\hline & +21 & $1(2.8)$ & $1(2.8)$ & - & - & - & - \\
\hline \multirow{3}{*}{$\begin{array}{l}\text { Poor (including double } \\
\text { abnormalities) }\end{array}$} & $\operatorname{inv}(3)$ & $0(0.0)$ & - & - & - & - & - \\
\hline & $\mathrm{t}(3 \mathrm{q})$ & $0(0.0)$ & - & - & - & - & - \\
\hline & $\operatorname{del}(3 q)$ & $0(0.0)$ & - & - & - & - & - \\
\hline Very poor & Complex & $1(2.8)$ & - & - & - & $1(2.8)$ & - \\
\hline
\end{tabular}

$M D S=$ myelodysplastic syndromes; $R A=$ refractory anaemia $; R A R S=$ refractory anaemia with ringed sideroblasts; $R C M D=$ refractory cytopaenia with multilineage dysplasia; $R A E B=$ refractory anaemia with excess blasts; $U$ = unclassified.

*As per the Revised International Prognostic Scoring System. ${ }^{25}$

${ }^{+}$The total dataset does not add up to 36 as some patients may have had more than one abnormality.

${ }^{\ddagger}$ Including two cases of MDS-U with a del(18p) abnormality and one other abnormality.

abnormalities were defined as two or more cells with the same whole chromosome gain/chromosome rearrangement or three or more cells with the same chromosome loss. A complex karyotype was defined as three or more cytogenetic abnormalities.
Ethical approval for this research was received from the Research \& Ethics Committee of the College of Medicine \& Health Sciences, Sultan Qaboos University (MREC \#896). 
Table 4: Abnormal karyotypes among Omani patients with myelodysplastic syndromes presenting to the Sultan Qaboos University Hospital, Muscat, Oman $(\mathrm{N}=36)$

$\begin{array}{lcccc}\text { Patient } & \text { Age/gender } & \text { MDS subtype* } & \text { Karyotype } & \begin{array}{c}\text { Survival in } \\ \text { months }\end{array} \\ 1 & 69 / \mathrm{M} & \text { MDS-U } & 45, \mathrm{X},-\mathrm{Y}[17] / 46, \mathrm{XY}[3] & 18 \\ 2 & 67 / \mathrm{F} & \text { MDS-U } & 46, \mathrm{XX}, \mathrm{del}(18)(\mathrm{p} 11)[20] & 5 \\ 3 & & & 16 \\ 4 & 67 / \mathrm{F} & \text { RAEB } & 46, \mathrm{XX}, \mathrm{add}(1)(\mathrm{q} 42) \operatorname{del}(13)(\mathrm{q} 31)[13] / 46, \mathrm{XX}[7] & 4 \\ 5 & \text { RCUD } & 47, \mathrm{XX},+21[17] / 46, \mathrm{XX}[1] & 7 \\ 6 & \text { 78/F } & \text { MDS-U } & 47, \mathrm{XX},+8[9] / 46, \mathrm{XX}[11] & 5 \\ 7 & 68 / \mathrm{F} & \text { RA } & 46, \mathrm{XX}, \mathrm{del}(5)(\mathrm{q} 15 \mathrm{q} 31), \mathrm{del}(11)(\mathrm{q} 23)[8] / 46, \mathrm{XX}[6] & 3\end{array}$

$M D S=$ myelodysplastic syndromes; $M=$ male $; U=$ unclassified $F=$ female $R A E B=$ refractory anaemia with excess blasts; $R C U D=$ refractory cytopaenia with unilineage dysplasia; $R A=$ refractory anaemia.

*Defined as per the criteria of the World Health Organization. ${ }^{23}$

\section{Cytogenetic and Patient Data from Oman}

A total of 36 Omani patients with MDS were successfully karyotyped. Of these, eight patients had refractory anaemia (RA; 22.2\%), three had RA with ringed siderolasts (8.3\%), 11 had refractory cytopaenia with multilineage dysplasia (30.6\%), six had RA with excess blasts (16.7\%) and eight had unclassified MDS (22.2\%). One of the patients with RA with ringed siderolasts had MDS associated with an isolated del(5q) abnormality. Cytopaenia with bilineage was observed in 15 patients (41.7\%), while cytopaenia with trilineage was seen in 13 patients (36.1\%). Most of the patients $(75.0 \%)$ had $<5 \%$ bone marrow blasts. A total of 29 patients received supportive therapy only (80.6\%). Seven patients had AML transformation (19.4\%). The mortality rate was $25.0 \%$. There was an equal number of male and female patients and the majority of the patients were over 60 years old (63.9\%) [Table 1]. The median follow-up period was 28 months (range: 3-70 months). Table 2 shows the distribution of MDS subtypes according to age and gender.

Overall, 26 patients (72.2\%) had normal karyotypes which indicated a good prognosis according to the Revised International Prognostic Scoring System (IPSS-R) [Table 3]. ${ }^{25}$ One patient had a normal variant and another had a non-clonal abnormality. Eight patients had abnormal karyotypes (22.2\%), of which two patients had clones which had trisomy 8 and one patient each had trisomy 21, a del(5)(q15q31) abnormality, a del(11)(q23) abnormality, an i(17)(q10) abnormality, a del(18)(p11) abnormality and an absent Y chromosome [Table 4]. Six of these eight patients also showed normal clones along with abnormal clones.

\section{Comparison of Omani Data with Other Populations}

The characteristics of Omani patients with MDS were compared to those previously reported from other populations [Table 5]. $3,7,11,13,15,16,22,26-33$ The median age of patients with MDS in Oman (65 years old) was lower than that reported from Europe (65-74 years old) but was higher compared to other Asian countries (50-60 years old). ${ }^{10,13,15,17,19-22,26,28,31}$ The median age of the patients in Tunisia was 60 years old. ${ }^{22}$ Brazilian patients had the youngest median age (29 years old). ${ }^{27}$ Among Omani patients, the male-to-female ratio was 1:1, which was in accordance with a sample from Thailand and close to ratios reported from Brazil (1.2:1) and Germany (1.3:1);,326,27 however, this finding was contrary to many other Asian countries and certain European, North American and African countries in which males outnumbered females., $711,13,15,22,28,30,31$ Further research is needed to determine a possible cause for this gender difference between populations.

The majority of Omani patients showed normal karyotypes (62.2\%) and were believed to have a good prognosis according to IPSS-R classifications. ${ }^{25}$ Only published data on the frequency of abnormal karyotypes from Japan (23.9\%) and China (37.1\%) were close to the data from Oman. ${ }^{16,28}$ Chromosomal abnormalities such as $\mathrm{i}(17 \mathrm{q})$, trisomy 21 and the absence of the $\mathrm{Y}$ chromosome were seen in one each of the Omani patients (2.8\% each). Studies from Germany, Japan and Argentina also reported patients with loss of the $\mathrm{Y}$ chromosome $(7.0 \%, 1.1 \%$ and $2.7 \%$, respectively); ${ }^{3,15,29}$ however, this abnormality was not observed among patients from Thailand, Switzerland or Brazil.,26,27 Similarly, trisomy 21 was not observed 


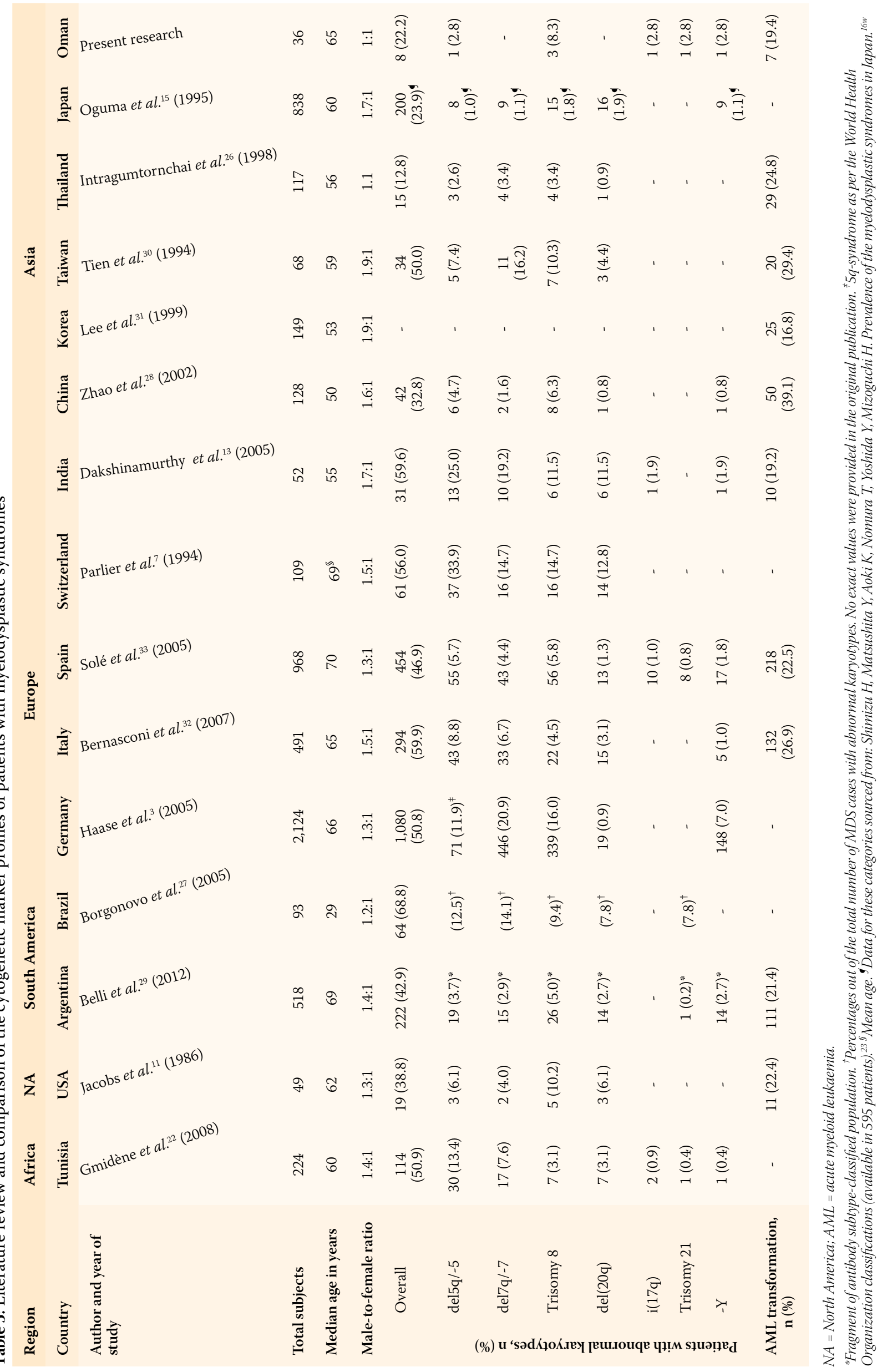


in Thailand or India. ${ }^{13,26}$ The USA had the lowest percentage of AML transformation (2.8\%), followed by Korea (16.8\%) and Oman (19.4\%). ${ }^{31}$

The overall percentage of abnormal karyotypes was lower among Omanis compared to other populations (22.2\% versus $23.9-68.8 \%$ ), although this may be due to the low number of patients included in the Omani sample. ${ }^{3,7,11,13,15,16,22,26-33}$ The highest percentage of patients with abnormal karyotypes was reported from Brazil. ${ }^{27}$ The frequency of cytogenetic abnormalities according to MDS subtype was found to be different among Omani patients when compared to other populations, with most Omani patients having normal karyotypes and thus a good prognosis. . $^{3,711,13,15,16,22,26-33}$

The current research sought to compare the cytogenetic characteristics of Omani patients with MDS to those reported among other geographic/ ethnic populations. A review of the literature revealed that this dataset constitutes the first report from an ethnic Omani population. However, verification of the findings of this research is needed with a larger sample. As the native Omani population is relatively small, numbering approximately 2.35 million in 2015, the number of patients with MDS presenting to SQUH was hence limited and the sample size too small to draw statistically significant conclusions. ${ }^{34}$ As such, it is recommended that the sample size be increased in future studies. Socioeconomic characteristics and access to the healthcare system may also contribute to MDS awareness and detection rates within a given population. The referral of suspected patients from rural healthcare centres to tertiary hospitals for cytogenetic testing could also increase the detection/confirmation of MDS markers for better characterisation.

\section{Conclusion}

To the best of the authors' knowledge, this report is the first from an Omani population detailing the cytogenetic characteristics of patients with MDS. These data may serve as a basis for further research in Oman and a comparison with other populations.

\section{CONFLICT OF INTEREST}

The authors declare no conflicts of interest.

\section{FUNDING}

No funding was received for this research.

\section{References}

1. Greenberg PL. Implications of pathogenetic and prognostic features for management of myelodysplastic syndromes. Lancet 2001; 357:1059-60. doi: 10.1016/S0140-6736(00)04306-3.

2. Pedersen-Bjergaard J, Philip P, Larsen SO, Andersson M, Daugaard G, Ersbøll J, et al. Therapy-related myelodysplasia and acute myeloid leukemia: Cytogenetic characteristics of 115 consecutive cases and risk in seven cohorts of patients treated intensively for malignant diseases in the Copenhagen series. Leukemia 1993; 7:1975-86

3. Haase D, Steidl C, Schanz J, Schabla R, Pfeilstöcker M, Nösslinger $\mathrm{T}$, et al. Correlation of cytogenetic findings with morphology, clinical course and prognosis in 2124 patients with MDS. Blood 2005; 106:787.

4. Boultwood J, Wainscoat JS. Gene silencing by DNA methylation in haematological malignancies. Br J Haematol 2007; 138:3-11. doi: 10.1111/j.1365-2141.2007.06604.x.

5. Mohamedali A, Gäken J, Twine NA, Ingram W, Westwood N, Lea NC, et al. Prevalence and prognostic significance of allelic imbalance by single-nucleotide polymorphism analysis in lowrisk myelodysplastic syndromes. Blood 2007; 110:3365-75. doi: 10.1182/blood-2007-03-079673.

6. Bejar R, Stevenson K, Abdel-Waheb O, Galili N, Nilsson B, Garcia-Manero G, et al. Clinical effect of point mutations in myelodysplastic syndromes. N Engl J Med 2011; 364:2496-506. doi: 10.1056/NEJMoa1013343.

7. Parlier V, van Melle G, Beris P, Schmidt PM, Tobler A, Haller E, et al. Hematologic, clinical, and cytogenetic analysis in 109 patients with primary myelodysplastic syndrome: Prognostic significance of morphology and chromosome findings. Cancer Genet Cytogenet 1994; 78:219-31. doi: 10.1016/0165-4608(94) 90094-9.

8. Pfeilstöcker M, Reisner R, Nösslinger T, Grüner H, Nowotny $H$, Tüchler $\mathrm{H}$, et al. Cross-validation of prognostic scores in myelodysplastic syndromes on 386 patients from a single institution confirms importance of cytogenetics. Br J Haematol 1999; 106:455-63. doi: 10.1046/j.1365-2141.1999.01559.x.

9. Solé F, Espinet B, Sanz GF, Cervera J, Calasanz MJ, Luño E, et al. Incidence, characterization and prognostic significance of chromosomal abnormalities in 640 patients with primary myelodysplastic syndromes: Grupo Cooperativo Español de Citogenética Hematológica. Br J Hematol 2000; 108:346-56. doi: 10.1046/j.1365-2141.2000.01868.x.

10. Aul C, Gattermann N, Heyll A, Germing U, Derigs G, Schneider W. Primary myelodysplastic syndromes: Analysis of prognostic factors in 235 patients and proposal for an improved scoring system. Leukemia 1992; 6:52-9.

11. Jacobs RH, Cornbleet MA, Vardiman JW, Larson RA, Le Beau MM, Rowley JD. Prognostic implications of morphology and karyotype in primary myelodysplastic syndromes. Blood 1986; 67:1765-72

12. Mitelman F. Geographic heterogeneity of chromosome aberrations in hematologic disorders. Cancer Genet Cytogenet 1986; 20:203-8.

13. Dakshinamurthy AG, Novitzky N, Bharadwaj R, Prakhya BM. Cytogenetic analysis of 52 Indian patients with de novo myelodysplastic syndromes: A comparative analysis of results with reports from Asia. Ann Hematol 2005; 84:298-303. doi: 10. 1007/s00277-004-0997-x.

14. Chan LC, Kwong YL, Liu HW, Chan TK, Todd D, Ching LM. Cytogenetic analysis of hematologic malignancies in Hong Kong: A study of 98 cases. Cancer Genet Cytogenet 1992; 62:154-9. doi: 10.1016/0165-4608(92)90255-7. 
15. Oguma S, Yoshida Y, Uchino H, Maekawa T, Nomura T, Mizoguchi H. Clinical characteristics of Japanese patients with primary myelodysplastic syndromes: A co-operative study based on 838 cases - Anemia Study Group of the Ministry of Health and Welfare. Leuk Res 1995; 19:219-25. doi: 10.1016/0145-2126 (94)00135-W.

16. Shimizu H, Matsushita Y, Aoki K, Nomura T, Yoshida Y, Mizoguchi H. Prevalence of the myelodysplastic syndromes in Japan. Int J Hematol 1995; 61:17-22.

17. Toyama K, Ohyashiki K, Yoshida Y, Abe T, Asanso S, Hirai H, et al. Clinical implications of chromosomal abnormalities in 401 patients with myelodysplastic syndromes: A multicentric study in Japan. Leukemia 1993; 7:499-508.

18. Yoshida Y, Oguma S, Uchino H, Maekawa T. Clinical features and prognosis of refractory myelodysplastic anemias: A Japanese Cooperative Study. Nihon Ketsueki Gakkai Zasshi 1987; 50:37-50.

19. Juneja SK, Imber M, Jouault H, Scoazec JY, Sigaux F, Sultan C. Hematological features of primary myelodysplastic syndromes (PMDS) at initial presentation: A study of 118 cases. J Clin Pathol 1983; 36:1129-35

20. Goasguen JE, Garand R, Bizet M, Bremond JL, Gardais J, Callat MP, et al. Prognostic factors of myelodysplastic syndromes: A simplified 3-D scoring system. Leuk Res 1990; 14:255-62. doi: 10.1016/ 0145-2126(90)90133-T.

21. Cunningham I, MacCallum SJ, Nicholls MD, Byth K, Hewson JW, Arnold B, et al. The myelodysplastic syndromes: An analysis of prognostic factors in 226 cases from a single institution. Br J Haematol 1995; 90:602-6. doi: 10.1111/j.1365-2141.1995. tb05590.x

22. Gmidène A, Sennana H, Fenaux P, Laatiri A, Zarrouk M, Bouaziz $\mathrm{H}$, et al. Cytogenetic abnormalities in Tunisian de novo myelodysplastic syndrome: A comparison with other populations. Leuk Res 2008; 32:1824-9. doi: 10.1016/j.leukres. 2008.05.002.

23. The International Agency for Research on Cancer; Swerdlow SH, Campo E, Harris NL, Jaffe ES, Pileri SA, et al. WHO Classification of Tumours of Haematopoietic and Lymphoid Tissue (IARC WHO Classification of Tumours), 4th ed. Geneva, Switzerland: World Health Organization, 2008.

24. McGowan-Jordan J, Simons A, Schmid M, Eds. An International System for Human Cytogenomic Nomenclature: ISCN 2016. Basel, Switzerland: Karger, 2016.
25. Greenberg PL, Tuechler H, Schanz J, Sanz G, Garcia-Manero G, Solé F, et al. Revised International Prognostic Scoring System for myelodysplastic syndromes. Blood 2012; 120:2454-65. doi: 10. 1182/blood-2012-03-420489.

26. Intragumtornchai T, Prayoonwiwat W, Swasdikul D, Suwanwela N, Chaimongkol B, Jootar S, et al. Myelodysplastic syndromes in Thailand: A retrospective pathologic and clinical analysis of 117 cases. Leuk Res 1998; 22:453-60. doi: 10.1016/S0145-2126 (98)00022-8

27. Borgonovo T, Ribeiro EM, Cornélio DA, Schmid-Braz AT, Jamur VR, Wuicik L, et al. Cytogenetic study of Brazilian patients with myelodysplastic syndrome (MDS). Genet Mol Biol 2005; 28:654-60. doi: 10.1590/S1415-47572005000500002.

28. Zhao WL, Xu L, Wu W, Yan H, Tang W, Hu J, et al. The myelodysplastic syndromes: Analysis of prognostic factor and comparison of prognostic systems in 128 Chinese patients from a single institution. Hematol J 2002; 3:137-44. doi: 10.1038/ sj.thj.6200173.

29. Belli CB, Bestach Y, Correa WA, Sakamoto F, Flores MG, Basquiera AL, et al. Prognostic relevance of cytogenetic systems in myelodysplastic syndromes. Leuk Lymphoma 2012; 53:1640-2. doi: 10.31 09/10428194.2012.661053.

30. Tien HF, Wang CH, Chuang SM, Chow JM, Lee FY, Liu MC, et al. Cytogenetic studies, ras mutation, and clinical characteristics in primary myelodysplastic syndromes: A study on 68 Chinese patients in Taiwan. Cancer Genet Cytogenet 1994; 74:40-9.

31. Lee JJ, Kim HJ, Chung IJ, Kim JS, Sohn SK, Kim BS, et al. Comparisons of prognostic scoring systems for myelodysplastic syndromes: A Korean multicenter study. Leuk Res 1999; 23:425-32. doi: 10.1016/S0145-2126(99)00032-6.

32. Bernasconi P, Klersy C, Boni M, Cavigliano PM, Calatroni S, Giardini I, et al. World Health Organization classification in combination with cytogenetic markers improves the prognostic stratification of patients with de novo primary myelodysplastic syndromes. Br J Haematol 2007; 137:193-205. doi: 10.1111/j.13652141.2007.06537.x

33. Solé F, Luño E, Sanzo C, Espinet B, Sanz GF, Cervera J, et al. Identification of novel cytogenetic markers with prognostic significance in a series of 968 patients with primary myelodysplastic syndromes. Haematologica 2005; 90:1168-78.

34. National Centre for Statistics and Information. Population clock. From: www.ncsi.gov.om/Pages/NCSI.aspx Accessed: Mar 2017. 